\title{
PENGARUH REKAYASA PENGAIRAN TERHADAP PRODUKTIVITAS BUDIDAYA PADI (Oryzasativa) SAWAH
}

\author{
Raflen Aril Gerungan ${ }^{1}$ \\ Mecky Christofel Telis Pandelaki² \\ Fakultas Sains dan Teknologi, Program Studi Biologi, Universitas Terbuka ${ }^{1}$ \\ Fakultas Pertanian, Program Studi Agribisnis, Universitas Sariputra Indonesia Tomohon ${ }^{2}$ \\ e-mail: raflenaril@ecampus.ut.ac.id1
}

\begin{abstract}
Rice farming always experiences water shortages in dry season which result in low productivity. In order to overcome this problem, efforts are needed in the form of irrigation technology (intermittent and water-saturated condition). The aims of this study is to determine the effect of intermittent irrigation and water-saturated condition irrigation on the production of rice plants. This study used a randomized block design (RCBD) as an environmental design with a split plot design. This study was conducted by making a plot of $4 \times 6$ meters, totaling to 24 plots. Between every two plots, there is a waterway 50 centimeters wide. Each plot has a waterway for water intake and discharge. Intermittent irrigation treatment was conducted by flooding the plots by water as high as 5 centimeters 3 times at 0-9 HST, 15-29 HST, 35-70 HST, and water drying was also carried out three times at 9-15 HST, 29-35 HST, and 70-80 HST. Water-saturated condition irrigation treatment was conducted by leaving the plots in a state of water saturation without any stagnant water from 0 HST until the production phase. During the treatment of intermittent and water-saturated condition irrigation, fertilizer had been given at a dose of $600 \mathrm{~kg} / \mathrm{ha}, 800$ $\mathrm{kg} / \mathrm{ha}, 1.000 \mathrm{~kg} / \mathrm{ha}$ and $1.200 \mathrm{~kg} / \mathrm{ha}$. The parameters observed in this study were the number of active tillers, the number of ears per panicle, the weight of a thousand grains, and the weight of the saplings. The results showed that intermittent and water-saturated condition irrigation did not have a significantly different effect on each parameter of rice production. The highest dry weight production both in intermittent and water-saturated condition irrigation was found in the plot with $1.200 \mathrm{~kg} / \mathrm{ha}$ fertilizer and the lowest dry weight production was from the plot with $600 \mathrm{~kg} / \mathrm{ha}$ fertilizer.
\end{abstract}

Keywords: intermittent, water-saturated condition, rice productivity.

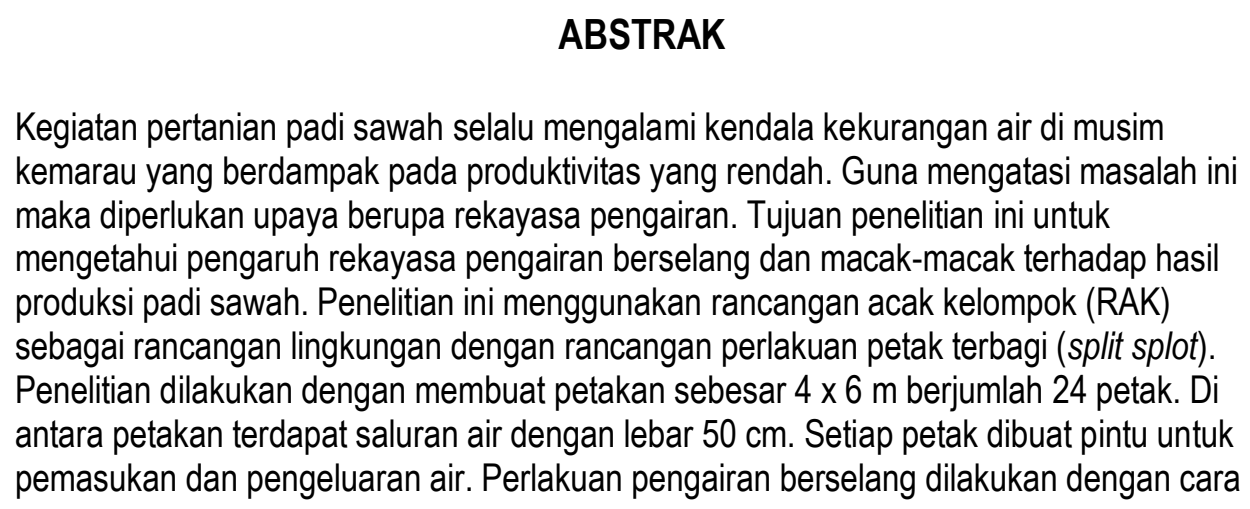


petak digenangi air setinggi $5 \mathrm{~cm}$ yang dilakukan sebanyak 3 kali pada 0-9HST, 15-29 HST, 35-70 HST, dan pengeringan air yang juga dilakukan sebanyak tiga kali yaitu pada 9-15 HST, 29-35 HST, dan 70-80 HST. Perlakuan pengairan macak-macak dilakukan dengan membuat petak percobaan selalu dalam keadaan jenuh air tanpa ada air yang tergenang mulai dari 0 HST hingga fase produksi. Pada perlakuan pengairan berselang dan macak-macak, juga diberi pupuk dengan dosis $600 \mathrm{~kg} / \mathrm{ha}, 800 \mathrm{~kg} / \mathrm{ha}, 1.000 \mathrm{~kg} / \mathrm{ha}$ dan $1.200 \mathrm{~kg} / \mathrm{ha}$. Parameter yang diamati pada penelitian ini adalah jumlah anakan aktif, jumlah bulir per malai, berat seribu butir, dan berat ubinan. Hasil penelitian menunjukan rekayasa pengairan berselang dan macak-macak tidak memberikan pengaruh yang berbeda nyata pada setiap parameter produksi padi. Produksi berat kering panen tertinggi baik pada pengairan berselang maupun macak-macak terdapat pada petak yang diberi pupuk $1.200 \mathrm{~kg} / \mathrm{ha}$ dan produksi berat kering terendah terdapat pada petak yang diberi pupuk $600 \mathrm{~kg} / \mathrm{ha}$.

Kata kunci: pengairan berselang, pengairan macak-macak, produktivitas padi.

Pengelolaan sumber daya alam dan lingkungan merupakan bagian yang penting untuk keberlangsungan daya dukung lingkungan terhadap kestabilan makhluk hidup di sekitarnya. Lingkungan yang baik akan mendukung setiap kebutuhan yang diperlukan oleh makhluk hidup baik itu berasal dari tanah, air dan udara. Budidaya padi sawah merupakan salah satu dari kegiatan pembudidayaan tanaman yang membutuhkan dukungan sumberdaya alam dan lingkungan. Daya dukung akan ketersediaan sumberdaya alam dan lingkungan akan mampu memberikan pengaruh yang baik terhadap pertumbuhan dan produksi tanaman. Tanah dengan kandungan hara dan air akan berperan penting dalam produktivitas tanaman. Astuti (2010) menyatakan bahwa air merupakan kebutuhan dasar tanaman untuk dapat tumbuh, berkembang dan berproduksi dengan baik. Lebih lanjut Kurnia (2004) menyebutkan bahwa air merupakan salah satu sumberdaya alam yang sangat esensial bagi sistem produksi pertanian.

Pengairan terus menerus pada budidaya padi sawah merupakan metode yang umum dilakukan oleh para petani dalam penggunaan air, pengairan ini membiarkan air tergenang pada tanaman mulai dari beberapa hari setelah tanam hingga beberapa hari sebelum panen. Namun pengairan terus-menerus akan kurang maksimal disaat musim kemarau dan pada saat area persawahan tersebut kekurangan air, ditambah dengan berkurangnya sumber-sumber air tanah karena pengalih fungsian hutan, maka ketersediaan air pada budidaya padi sawah di masa yang akan datang seiring waktu mulai berkurang. Dalam sebuah riset pada petani yang menggarap lahan rawan kekeringan di Desa Jatirunggo Kabupaten Semarang, terlihat bahwa dengan adanya perubahan iklim musim kemarau semakin panjang menyebabkan dampak peningkatan resiko gagal panen, kerusakan hasil panen, dan menurunkan kualitas panen (Ida \& Suryanto, 2015). Demikian juga pada sentra budidaya padi di Kabupaten Seram Bagian Barat, Kabupaten Maluku Tengah, dan Kabupaten Buru, penurunan produksi padi akibat perubahan iklim pernahmencapai $17 \%$ di tahun 2001 dan 2002 (Agung Budi, 2016). 
Mengatasi permasalahan di atas, maka diperlukan suatu teknologi pengairan yang dapat diterapkan untuk mengontrol pengairan pada budidaya padi sawah. Penerapan teknologi dalam budidaya memiliki tujuan untuk menyesuaikan diri terhadap lingkungan tumbuh sehingga diperoleh pertumbuhan dan produktivitas yang optimal (Utami, Priyatmojo, \& Subejo, 2016). Rekayasa pengairan merupakan teknologi hemat air yang terdiri atas pengairan berselang dan macak-macak yang dapat mengontrol pengairan pada budidaya padi sawah.Pengairan berselang (intermittent) merupakan penggenangan air dilakukan pada selang waktu tertentu dan pengairan macak-macak di mana lahan tidak digenangi air tetapi cukup hanya dijenuhi (water saturated conditions) (Subagyono, Dariah, Surmaini, \& Kurnia, 2008). Selain menghemat air, pengairan berselang dapat mengurangi emisi gas metana dari lahan sawah dan pengairan macak-macak merupakan rekayasa pengairan yang mampu memenuhi kebutuhan air tanaman pada kondisi ketersediaan air yang sangat terbatas dan meningkatkan nilai dayaguna air (Surmaini, Runtunuwu, \& Las, 2015).

Pengairan pada budidaya padi sawah di KecamatanTondano Selatan Kabupaten Minahasa masih tergantung dengan sistem pengairan terus menerus (continous flooding flowing) sehingga pada saat jumlah air yang melimpah konsumsi atau penggunaan air tidak akan terganggu, tetapi sebaliknya jika debit air berkurang ditambah dengan kurangnya pengetahuan akan penerapan rekayasa pengairan, maka proses pembudidayaan padi sawah akan mengalamigangguan. Sesuai penuturan para petani padi sawah di Kecamatan Tondano Selatan dan sekitarnya sistem pengairan yang diterapkan merupakan pengairan terus-menerus dari awal yaitu beberapa hari setelah penanaman hingga kurang lebih satu minggu sebelum panen, mereka juga menuturkan bahwa penerapan rekayasa pengairan selama ini belum pernah diterapkan.

Tujuan penelitian ini untuk mengetahui pengaruh rekayasa pengairan berselang dan macakmacak terhadap hasil produksi padi sawah.

\section{METODE}

Penelitian dilaksanakan pada bulan Februari sampai Juni 2019 di perkebunan padi sawah Kecamatan Tondano Selatan Minahasa, Sulawesi Utara dengan jenis tanah aluvial. Bahan yang digunakan dalam penelitian ini yaitu: Varietas padi IR-64 hasil pembibitan petani setempat, pupuk organik petro ganik jenis G 095/organik/bsp/IX/2005 (C Organik:12,5\%, C/N Ratio:10-25, pH:4-8, Kadar air:4-12\%). Alat yang digunakan mistar \& meteran rol, timbangan analitik, timbangan kapasitas $10 \mathrm{~kg}$, oven, patok arsiran tinggi 1.5 meter berjumlah 98 buah, karung, plastik, label, dan pompa air alkon.

Rancangan penelitian menggunakan rancangan acak kelompok (RAK) dengan rancangan perlakuannya adalah rancangan petak terbagi (split-plot) dengan tiga ulangan secara acak.

Perlakuan rekayasapengairan dibagi menjadi dua petak utama yaitu pengairan berselang $=A 1$, pada pengairan berselang petak percobaan digenangi air setinggi kurang lebih $5 \mathrm{~cm}$ sebanyak tiga kali yaitu 0-9 Hari Setelah Tanam (HST), 15-29 HST, dan 35-70 HST, selanjutnya dilakukan pengeringan air sebanyak tiga kali yaitu 9-15 HST, 29-35 HST, dan 70-80 HST dan pengairan macak-macak = A2, pada pengairan macak-macak petak percobaannya selalu dalam keadaan tidak 
tergenang air tetapi dalam keadaan jenuh air. Kemudian dibagi menjadi empat anak petak untuk pemberian pupuk organik pada $0 \mathrm{HST}, 21 \mathrm{HST}, 42 \mathrm{HST}$ dengan dosis $600 \mathrm{~kg} / \mathrm{ha}=\mathrm{P} 1,800 \mathrm{~kg} / \mathrm{ha}=$ P2, $1000 \mathrm{~kg} / \mathrm{ha}=\mathrm{P} 3$, dan $1200 \mathrm{~kg} / \mathrm{ha}=\mathrm{P} 4$. Parameter yang diamati adalah jumlah anakan aktif 14 Minggu Setelah Tanam (MST), jumlah bulir per malai 3 hari sebelum panen, bobot seribu butir pada saat panen, berat kering panen ubinan pada saat panen. Analisis data dalam penelitian ini menggunakan analisis General Linear Model (GLM) Univariate yang dibutuhkan untuk menganalisis racangan penelitian RAK Split-Splot dengan menggunakan software IBM SPSS Statistik versi 19.

\section{HASIL DAN PEMBAHASAN}

1. Jumlah Anakan Aktif

Jumlah anakan aktif ialah anakan padi yang telah mengeluarkan malai, perlakuan rekayasa pengairan memberikan pengaruh yang tidak berbeda nyata terhadap jumlah anakan aktif, berdasarkan analisis statistik pada taraf signifikansi $\alpha=0,05$, disajikan dalam lampiran 1 tabel test of between-subjects effects. Diperoleh nilai $F_{h}(1,08)<F_{t}(18,51)$ dan nilai Sig $(0,408)>a(0,05)$ untuk rekayasa pengairan.

Rata-rata jumlah anakan aktif 84 HST terbanyak terdapat pada pengairan berselang (intermittent) yaitu 30 anakan aktif walaupun jumlahnya tidak berbeda jauh dengan pengairan macakmacak yaitu 29 anakan aktif seperti pada Gambar 1.

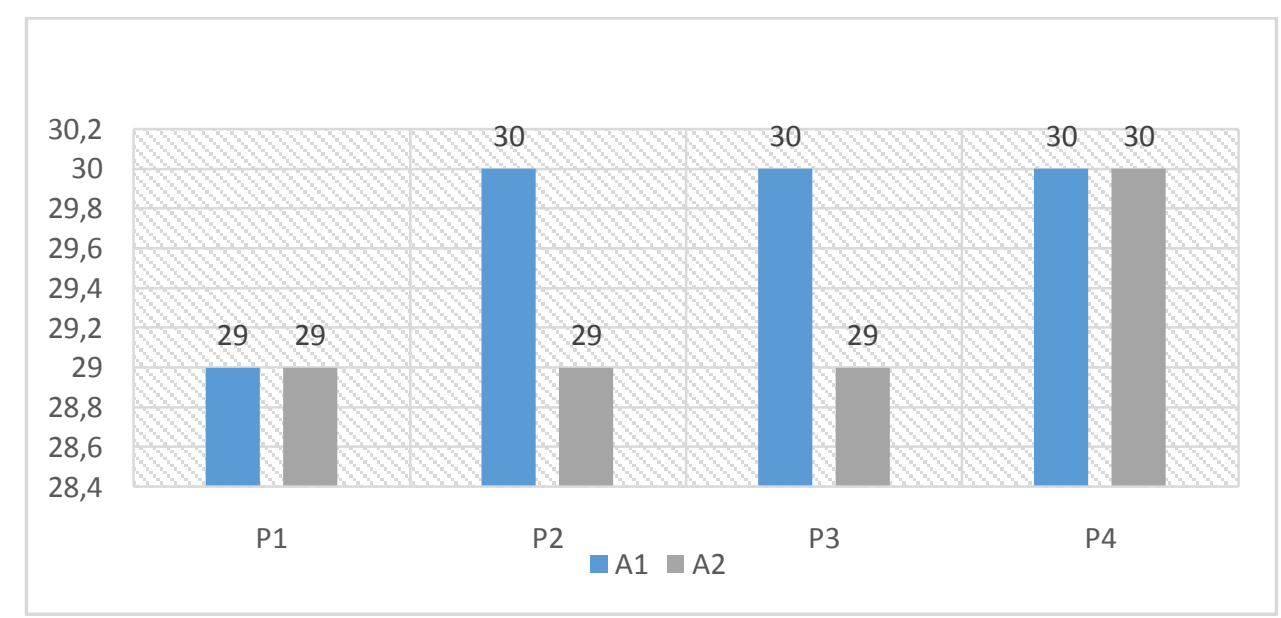

Ket: A1: Pengairan Berselang, A2: Pengairan Macak-Macak

P: Pupuk Organik (P1: 600kg/Ha), (P2: 800kg/Ha), (P3: 1.000kg/Ha), (P4: 1.200kh/Ha)

\section{Gambar 1. Rata-rata jumlah anakan aktif}

Berdasarkan Gambar 1 dan hasil analisis statistik dapat dijelaskan bahwa pengairan berselang dan macak-macak memberikan pengaruh yang tidak berbeda nyata pada jumlah anakan aktif. Hal ini menunjukkan bahwa ketersediaan air pada fase vegetatif tanaman padi masih terpenuhi. Faktor pendukung lainnya juga adalah peran ketersediaan air tersebut di atas secara fisiologis pada tanaman padi, dimana dalam penelitian ini pengairan membantu unsur hara dan mineral lainnya terlarut hingga dapat diserap oleh akar, sebagai reaktan dalam proses metabolisme, air juga 
berperan dalam pembesaran dan perpanjangan sel, sehingga peran tersebut membantu dalam proses pertumbuhan anakan aktif. Selain itu dapat juga dilihat pada ciri-ciri tampak luar padi, dimana anakan aktif tidak mengalami kekerdilan, ini menunjukan bahwa proses pertumbuhan dengan adanya pemanjangan sel dapat berjalan dengan baik. Menurut (Astuti, 2010) menunjukkan bahwa perlakuan pengairan yaitu tergenang, berselang, dan macak-macak tidak memberikan pengaruh yang berbeda nyata terhadap jumlah anakan aktif. Lebih lanjut (Naharia, Saeni, Sabihan, \& Burhan, 2005) dalam penelitiannya dimana hasil anakan aktif pada pengairan berselang dan macak-macak tidak berbeda jauh jumlahnya atau tidak ada pengaruh beda nyata.

\section{Jumlah Bulir Per Malai}

Jumlah bulir per malai adalah bulir-bulir padi yang dihasilkan baik bulir yang berisi sempurna dan tidak sempurna. Perlakuan rekayasa pengairan memberikan pengaruh tidak berbeda nyata terhadap jumlah bulir per malai, sesuai hasil analisis statistik pada taraf signifikansi $\alpha=0,05$, disajikan dalam lampiran 2 tabel test of between-subjects effects. Diperoleh nilai $F_{h}(3,05)<F_{t}(18,51)$ dan nilai Sig $(0,222)>a(0,05)$ untuk rekayasa pengairan.

Rata-rata jumlah bulir per malai 109 HST atau 3 hari sebelum panen untuk pengairan berselang (intermittent) dengan jumlah terbanyak terdapat pada dosis pupuk $1200 \mathrm{~kg} / \mathrm{ha}$ sebanyak 151 bulir, jumlah terendah pada dosis pupuk $600 \mathrm{~kg} / \mathrm{ha}$ sebanyak 132 bulir. Pada pengarian macakmacak jumlah terbanyak pada dosis pupuk $1.200 \mathrm{~kg} / \mathrm{ha}$ sebanyak 150 bulir, jumlah terendah pada dosis 600 kg/ha sebanyak 138 bulir seperti pada Gambar 2.

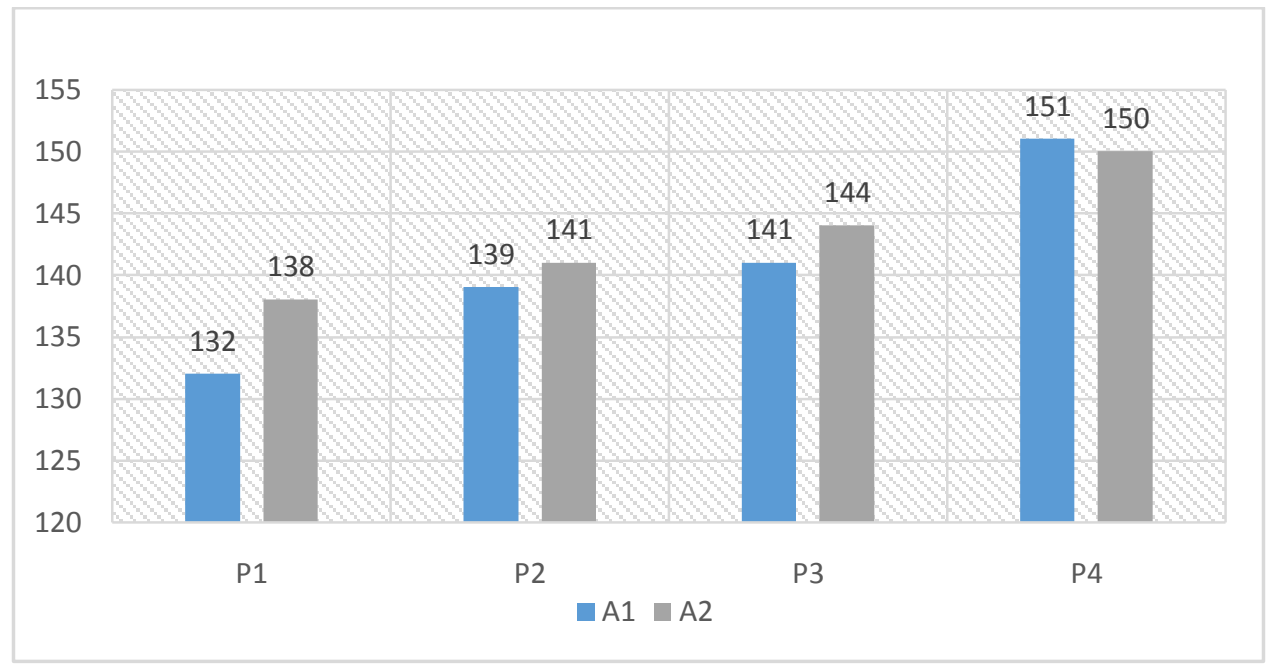

Ket: A1: Pengairan Berselang, A2: Pengairan Macak-Macak

P: Pupuk Organik (P1: 600kg/Ha), (P2: 800kg/Ha), (P3: 1.000kg/Ha), (P4: 1.200kh/Ha)

Gambar 2. Rata-rata jumlah bulir per malai.

Jumlah bulir tiap malai yang dihitung dalam penelitian ini yaitu keseluruhan bulir-bulir yang dihasilkan, penelitian ini menunjukkan bahwa rekayasa pengairan tidak memberikan pengaruh 
berbeda nyata. (Juliardi \& Ruskandar, 2006) pada penelitiannya menyatakan kebutuhan air untuk pengolahan tanah sampai siap tanam (30 hari) konsumsi air 20\% dari total kebutuhan air untuk padi sawah dan fase bunting sampai pengisian bulir (15 hari) konsumsi air sebanyak $35 \%$, sesuai data tersebut menunjukan dari awal penanaman hingga masuk fase bunting tidak membutuhkan air banyak atau tidak perlu adanya pengairan tergenang terus menerus (continous flooding flowing) hingga pengisian bulir selesai atau bulir dihasilkan. Lebih lanjut Sugiono \& Saputro (2016) dalam penelitiannya menjelaskan bahwa penggunaan rekayasa pengairan pada berbagai sistem tanam untuk melihat respon pertumbuhan dan hasil padi pada parameter bulir permalai untuk beberapa genotip memberikan pengaruh tidak berbeda nyata.

\section{Berat Seribu Butir}

Analisis berat seribu butir padi untuk perlakuan rekayasa pengairan memberikan pengaruh yang tidak berbeda nyata. Sesuai hasil analisis statistik pada taraf signifikansi $a=0,05$, disajikan dalam lampiran 3 tabel test of between-subjects effects. Diperoleh nilai $F_{h}(0,533)<F_{t}(18,51)$ dan nilai Sig $(0,541)>a(0,05)$ untuk rekayasa pengairan.

Rata-rata jumlah berat seribu butir 112 HST pada pengairan berselang (intermittent) nilai berat tertinggi pada dosis pupuk $600 \mathrm{~kg} / \mathrm{ha}$ yaitu $24.2 \mathrm{gr}$, berat terendah pada dosis pupuk $1000 \mathrm{~kg} / \mathrm{ha}$ yaitu 23,6 gr. Pada pengairan macak-macak nilai berat tertinggi pada dosis pupuk $800 \mathrm{~kg} / \mathrm{ha}$ yaitu 24,6 gr, berat terendah pada dosis pupuk 1200 kg/ha yaitu $23 \mathrm{gr}$. Rata-rata jumlah berat seribu butir padi disajikan dalam Gambar 3.

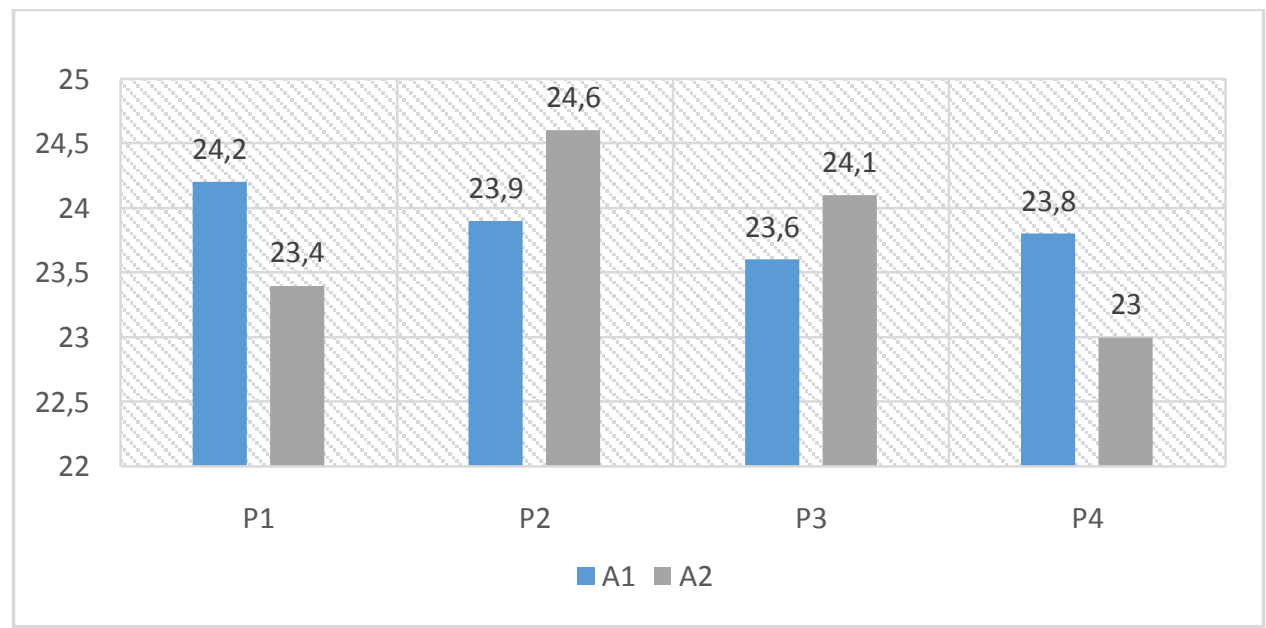

Ket: A1: Pengairan Berselang, A2: Pengairan Macak-Macak

P: Pupuk Organik (P1: 600kg/Ha), (P2: 800kg/Ha), (P3: 1000kg/Ha), (P4: 1200kh/Ha)

Gambar 3. Rata-rata berat seribu butir

Berat seribu butir yang dihasilkan penelitian menunjukkan rekayasa pengairan memberikan pengaruh tidak berbeda nyata. Hal ini disebabkan oleh ketersediaan unsur hara yang dipengaruhi oleh pengairan yang diterapkan. Dimana dengan adanya pengairan tersebut membuat ketersediaan 
unsur hara dapat diserap oleh akar. Unsur hara yang terserap terdiri dari hara makro dan mikro. Unsur hara makro yaitu nitrogen, fosfor, dan kalium. (Kloepper, 1993) menyatakan penyerapan fosfor akan memberikan manfaat sebagai pengangkut energi hasil metabolisme dalam tanaman, merangsang pembungaan dan pembuahan, merangsang pembentukan biji, merangsang pembelahan sel, dan memperbesar jaringan sel. Hasil penelitian berat seribu butir di atas senada dengan penelitian Arsana, Yahya, Lontoh, \& Pane (2003) dimana perlakuan rekayasa pengairan baik macak-macak dan berselang memberikan pengaruh tidak berbeda nyata pada bobot 1000 butir padi. Penggunaan rekayasa pengairan pada sistem tanam untuk melihat respon pertumbuhan dan hasil padi pada bobot 1000 butir tidak memberikan pengaruh berbeda nyata (Sugiono \& Saputro, 2016).

\section{Berat Kering Panen (BKP) Ubinan}

Hasil analisis statistik berat unbinan dengan berat kering 14\% untuk perlakuan rekayasa pengairan memberikan pengaruh tidak berbeda nyata terhadap Berat Kering Panen (BKP) ubinan. Sesuai hasil analisis statistik pada taraf signifikansi $\alpha=0,05$, disajikan dalam lampiran 4 tabel test of between-subjects effects. Diperoleh nilai $F_{h}(0,231)<F_{t}(18,51)$ dan nilai Sig $(0,678)>a(0,05)$ untuk rekayasa pengairan.

Perlakuan rekayasa pengairan memberikan pengaruh yang tidak berbedah nyata, rata-rata nilai jumlah BKP ubinan pada 116 HST untuk pengairan berselang (intermittent) tertinggi pada dosis pupuk $1.200 \mathrm{~kg} / \mathrm{ha}$ yaitu 7,15 ton $\mathrm{kg} / \mathrm{ha}$, terendah pada dosis pupuk $600 \mathrm{~kg} / \mathrm{ha}$ yaitu 6,15 ton $\mathrm{kg} / \mathrm{ha}$. Pada pengairan macak-macak nilai berat tertinggi pada dosis pupuk $1.200 \mathrm{~kg} / \mathrm{ha}$ yaitu 6,83 ton $\mathrm{kg} / \mathrm{ha}$, nilai berat terendah pada dosis pupuk $600 \mathrm{~kg} / \mathrm{ha}$ yaitu 6,61 ton $\mathrm{kg} / \mathrm{ha}$.

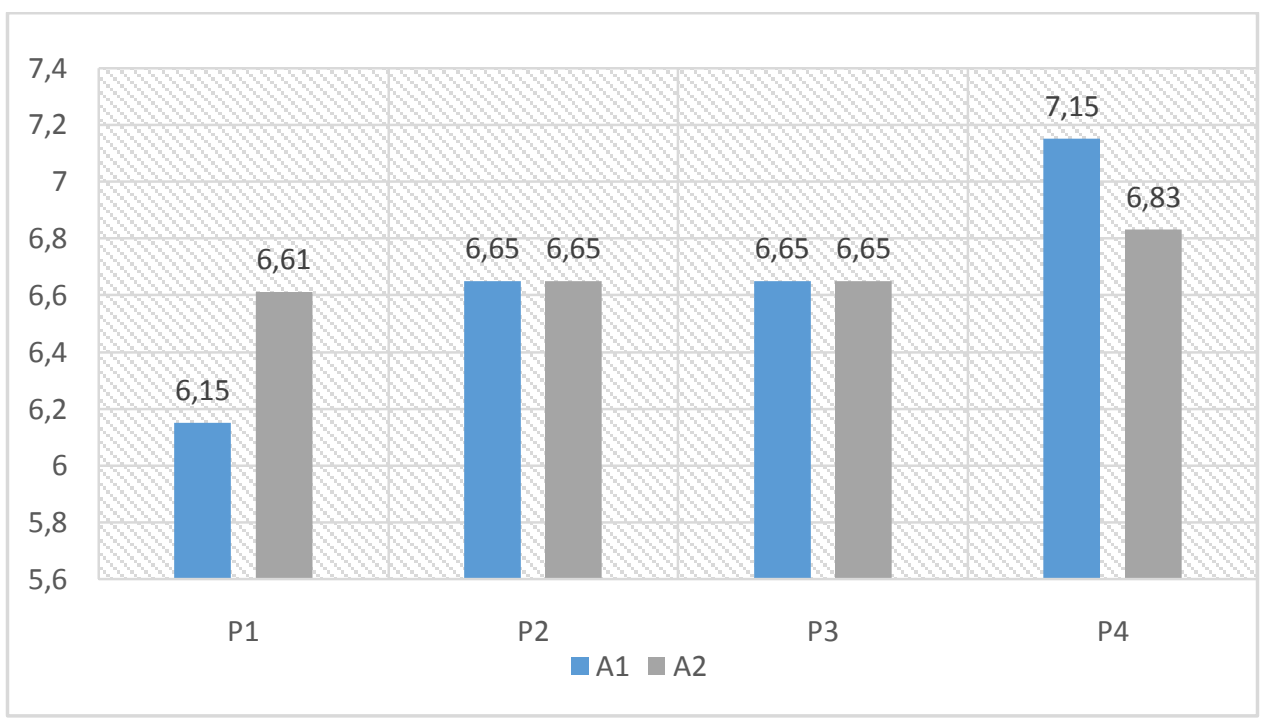

Ket: A1: Pengairan Berselang, A2: Pengairan Macak-Macak

P: Pupuk Organik (P1: 600kg/Ha), (P2: 800kg/Ha), (P3: 1.000kg/Ha), (P4: 1.200kh/Ha)

Gambar 4. Rata-rata jumlah berat kering panen ubinan (kg/ha) 
Berat kering panen (BKP) ubinan menunjukkan pada penerapan rekayasa pengairan baik berselang maupun macak-macak tidak memberikan pengaruh yang berbeda nyata. Naharia et al., (2005) dalam penelitiannya menunjukkan bahwa penggunaan pengairan berselang maupun macakmacak memberikan pengaruh tidak berbeda nyata terhadap hasil BKP. Hasil penelitian pada setiap parameter produksi di atas dengan penerapan rekayasa pengairan berselang dan macak-macak tidak memberikan pengaruh yang berbeda nyata namun hal tersebut bukan berarti memberikan hasil yang kurang bagus tetapi sebaliknya, hasil menunjukkan bahwa penerapan rekayasan pengairan pada penlitian ini tidak menurunkan jumlah hasil produksi dari tanaman padi.

Secara fisiologis air berperan penting dalam tanaman padi, pengairan membantu pelarutan bahan organik dan mineral lainnya, untuk dapat diserap oleh akar serta menjaga tanaman tidak mengalami cekaman air (water stress), walaupun daun padi berbentuk lanset sebagai model adaptasi untuk meminimalisir kehilangan air, tapi padi juga tetap mengalami pengeluaran air melalui transpirasi pada daun dan air juga digunakan pada proses fotosintesis. (Noggle \& Fritz, 1983) menyatakan air berfungsi sebagai: 1) Senyawa utama pembetukan protoplasma, 2) Pelarut untuk mineral-mineral dan nutrisi yang ada di dalam tanah untuk dapat diangkut atau diserap oleh akar dan disuplai melalui sel satu ke sel lainnya hingga ke seluruh bagian tubuh, 3) Media terjadinya proses metabolisme, 4) Sebagai reaktan dalam dalam sejumlah reaksi metabolisme, 5) Sebagai penghasil hidrogen dalam proses fotosintesis, 6) Menjaga turgiditas sel dan berperan sebagai tenaga mekanik dalam pembesaran sel, 7) Berperan dalam perpanjangan sel, 8) Pengatur gerakan tanaman seperti membuka dan menutupnya stomata.

Kebutuhan air pada padi dalam penelitian ini ada pada fase-fase tertentu dimana tanaman padi membutuhkan penggenangan air dan ada fase juga dimana tanaman padi dikondisikan pada air yang macak-macak, menurut Subagyono, Dariah, Surmaini, \& Kurnia (2008) peranan air sangat penting pada saat pembentukan anakan (vegetatif) dan awal fase pemasakan (generatif), sebaliknya pada akhir fase vegetatif dan akhir fase pemasakan. Penelitian ini menunjukkan rekayasa pengairan berselang dan macak-macak sanggup memenuhi kebutuhan konsumsi air padi sawah, hal ini terlihat pada setiap parameter pengukuran yang diamati.

Terpenuhinya kebutuhan air dengan pengairan berselang dan macak-macak dapat juga dilihat pada beberapa indikator yang bisa diamati secara langsung. Adapun indikator tersebut yaitu tanaman padi mengalami cekaman air (water stress) daun terlihat terbakar, tanaman padi kerdil, jumlah anakan sedikit, jumlah gabah hampa banyak, daun tergulung mulai dari ujung daun, pembungaan mengalami penundaan. Tapi sebaliknya pada penelitian ini tidak didapati indikator water stress pada padiseperti di atas.

Aspek umur lahan persawahan dapat juga menjadi faktor pemenuhan kebutuhan air. Aspek umur lahan sawah lama dan bukaan baru dapat dilihat juga dari perkembangan dan pembentukan tapak bajak (plow pan), di temukan di Nigeria bahwa pembentukan plow pan dengan tekstur lahan lempung berpasir setelah 3 tahun pengolahan tanah budidaya padi sawah. Lebih lanjut di Khyusu (Jepang) dengan tanah polder bertekstur liat setelah lahan umur 10-12 tahun belum ditemukan plow pan, pembentukan setelah pengolahan 50 tahun dan plow pan akan bekerja baik setelah lebih dari 
200 tahun (Moormann \& Breemen, 1978). Jadi lahan sawah yang sudah lama digunakan telah memiliki lapisan yang kedap air di bawah zona pengolahan tanah yang sering disebut lapisan tapak bajak (plow pan). Adanya plow pan memberikan efisiensi dalam pengelolaan penghematan air, sebaliknya pada lahan persawahan yang baru belum memiliki plow pan sehingga penggunaan air akan lebih tinggi dan bisa menyebabkan sulitnya dalam pengelolaan penghematan air, ini disebabkan merembesnya air melalui pori-pori tanah pada zona dibawah pengolahan tanah. Subagyono et al., (2008) menyatakan pengolahan air untuk lahan sawah lama dan bukaan baru harus dibedakan, karenapada sawah lama umumnya telah terbentuk lapisan kedap air di bawah zona pengolahan tanah yang sering (plow pan), sedangkan pada sawah baru lapisan ini belum terbentuk. Dari segi kebutuhan air sawah lama akan lebih efisein dibanding sawah bukaan baru karena sedikit terjadi kehilangan air melalui perkolasi.

Pengairan berselang dan macak-macak mampu memberikan kesempatan aerasi dalam tanah sehingga memudahkan penangkapan oksigen oleh akar, mengaktifasi mikroorganisme yang berperan di dalam tanah, menyeragamkan pemasakan gabah. BPTP Sulawesi Tenggara, (2012) atau Balai Pengkajian Teknologi Pertanian mempublikasikan bahwa pengairan berselang mampu bersinergi dengan pemupukan, menekan keracunan tanaman yang diakibatkan oleh terakumulasinya zat besi (Fe) dengan tanah, dapat menghambat perkembangan hama penggerek batang, keong mas, wereng coklat, dan penyakit pada tanaman padi yaitu busuk batang dan busuk pelepah daun, serta tanaman padi lebih tahan rebah karena akarnya yang lebih dalam.

Sehingga walaupun dengan kondisi air yang tidak berkelimpahan dengan melakukan penerapan rekayasa pengairan, budidaya padi sawah dapat terpenuhi kebutuhan airnya untuk pertumbuhan dan produktivitas tanaman padi.

Penggunaan pupuk organik menjadi faktor ketersediaan unsur hara untuk menunjang produktivitas budidaya padi. Masuknya unsur hara dalam tanah akan mampu meningkatkan daya restorasi tanah menjadi gembur sehingga ketersediaan hara bisa dipergunakan oleh tanaman padi. Unsur hara merupakan nutrisi yang dibutuhkan untuk pertumbuhan dan produktivitas, mampu membentuk tekstur tanah menjadi tanah yang mudah beraerasi, mengaktifkan kembali mikroorganisme tanah yang bekerja pada proses penggemburan tanah, dan memberikan peran untuk meningkatkan $\mathrm{C}$ organik di dalam tanah. Karakteristik pupuk organik yang ketersediaanya lambat (slow realese) menjadikan suatu keuntungan bagi produktivitas tanaman semusim. Menurut Raihan \& Saleh, (2009) bahwa pelepasan unsur hara yang berlangsung lambat (slow realese) menguntungkan bagi pertumbuhan tanaman semusim, karena ketersediaan unsur hara tersebut yang bersinambung selama fase vegetatif hingga fase reproduktif. Pupuk organik sebagai bahan pembenah tanah (soil conditioner) dapat meningkatkan kandungan C-organik dalam tanah membantu dalam mencegah terjadinya erosi dan mengurangi terjadinya retakan tanah. Selain itu mampu memperbaiki sifat fisik, kimia dan biologi tanah antara lain meningkatkan kelembaban tanah dan memperbaiki porositas tanah, serta kandungan hara dalam tanah (Yunizar, 2013).

Penggunaan pupuk organik 5,10 Ton/Ha dan penggunaan pupuk anorganik187,5 kg Urea/ha $+56,25 \mathrm{~kg} \mathrm{SP}-36 / \mathrm{ha}+56,25 \mathrm{~kg} \mathrm{KCL} / \mathrm{ha}$ menunjukan bahwa penggunaan kedua perlakuan pupuk 
tersebut memberikan pengaruh tidak berbeda nyata pada produksi padi (berat kering panen) (Padmanabha, Arthagama, \& Dibia, 2014). Pengaplikasian pupuk organik dengan bahan dasar jenis tanaman berbeda tetap memberikan pengaruh terhadap pertumbuhan dan produksi padi (Paulus, 2013).

\section{SIMPULAN DAN SARAN}

Simpulan penelitian ini bahwa penerapan rekayasapengairan berselang dan macak-macak tidak memberikan pengaruh yang berbeda nyata pada parameter produksi padi yaitu jumlah anakan aktif, jumlah bulir per malai, berat seribu butir, dan berat ubinan. Produksi berat kering panen tertinggi baik pada pengairan berselang maupun macak-macak terdapat pada petak yang diberi pupuk 1.200 $\mathrm{kg} / \mathrm{ha}$ dan produksiberatkering terendah terdapat pada petak yang diberi pupuk $600 \mathrm{~kg} / \mathrm{ha}$.

Saran, adanya penelitian lebih lanjut tentang tinggi rendahnya kadar konsumsi air pengairan berselang dan macak-macak pada budidaya padi dengan penggunaan media terkontrol dan menganalisis pengaruh air terhadap fisiologis tanaman padi dengan penggunaan pupuk organik yang memiliki kandungan C 12,5\% terhadap produktivitas budidaya padi sawah.

\section{UCAPAN TERIMA KASIH}

Kami mengucapkan terima kasih kepada DRPM Ristekdikti yang telah menyokong penelitian ini dalam bentuk dana penelitian dengan skema penelitian dosen pemula (PDP) dan seluruh tim peneliti yang telah bekerjakeras.

\section{REFERENSI}

Agung Budi, S. (2016). Pengaruh perubahan iklim terhadap produksi tanaman pangan di Provinsi Maluku. Jurnal Penelitian Pertanian Tanaman Pangan, 35(1), 29-38. Retrieved from http://repository.pertanian.go.id/handle/123456789/1446.

Arsana, D., Yahya, S., Lontoh, A. P., \& Pane, H. (2003). Hubungan antara penggenangan dini dan potensi redoks, produksi etilen dan pengaruhnya terhadap pertumbuhan dan hasil padi (Oryza sativa) sistem tabela. Jurnal Agronomi Indonesia (Indonesian Journal of Agronomy), 31(2), 37-41. https://doi.org/10.24831/jai.v31i2.1463.

Astuti, D. N. (2010). Pengaruh sistem pengairan terhadap pertumbuhan dan produktivitas beberapa varietas padi sawah (Oryza sativa L.). Retrieved September 23, 2019, from http://repository.ipb.ac.id/handle/123456789/27125.

BPTP Sulawesi Tenggara. (2012). Teknologi hemat air di lahan sawah irigasi. Retrieved September 23, 2019, from http://www.litbang.pertanian.go.id/info-aktual/1220/.

Ida, N. H., \& Suryanto. (2015). Pengaruh perubahan iklim terhadap produksi pertanian dan strategi adaptasi pada lahan rawan kekeringan. Jurnal Ekonomi Dan Studi Pembangunan, 16(1), 4252. https://doi.org/https://doi.org/10.18196/jesp.2015.0040.42-52.

Juliardi, I., \& Ruskandar, A. (2006). Teknik mengairi padi kalau macak-macak cukup, mengapa harus digenang. Sinar Tani. Retrieved from http://www.litbang.pertanian.go.id/artikel/133/pdf/Teknik Mengairi Padi : Kalau macak-macak cukup, mengapa harus digenang?.pdf. 
Kloepper, J. (1993). Plant growth-promoting rhizobacteria as biological control agents p. 255-274. In F.Blaine Metting, Jr. (Ed.). Soil microbiology ecology, Applications in Agricultural and Environmental Management. New York: Marcel Dekker, Inc.

Kurnia, U. (2004). Prospek pengairan pertanian tanaman semusim lahan kering. Jurnal Litbang Pertanian, 23(4), 230-138.

Moormann, F., \& Breemen, N. (1978). Rice: soil, water, land (Second). Manila: International Rice Research Institute.

Naharia, O., Saeni, M. S., Sabihan, S., \& Burhan, H. (2005). Teknologi pengairan dan pengolahan tanah pada budidaya padi sawah untuk mitigasi gas metana $\left(\mathrm{CH}_{4}\right)$ [Irrigation and soil cultivation technology on rice field for mitigation of methane $\left(\mathrm{CH}_{4}\right)$ gas emission]. Berita Biologi : Jurnal IImu IImu Hayati, (April), 173-180. https://doi.org/10.14203/beritabiologi.v7i4.880.

Noggle, G. ., \& Fritz, G. (1983). Introductory plant physiology. New Jersey: Prentice-Hall, Inc. Englewood Cliffs.

Padmanabha, I. G., Arthagama, I. D. M., \& Dibia, I. N. (2014). Pengaruh dosis pupuk organik dan anorganik terhadap hasil padi ( Oriza sativa $\mathrm{L}$.) dan sifat kimia tanah pada inceptisol Kerambitan Tabanan. E-Jurnal Agroekoteknologi Tropika, 3(1), 41-50.

Paulus, J. M. (2013). Aplikasi pupuk hijau terhadap pertumbuhan dan produksi padi sawah (Oryza sativa L.). In Pertanian Organik: Solusi mewujudkan produksi pangan yang aman dan ramah lingkungan serta meningkatkan pendapatan petani (pp. 305-310). Yogyakarta: Jurusan Tanah, Fakultas Pertanian UGM.

Raihan, S., \& Saleh, M. (2009). Pengaruh bahan organik terhadap tanaman padi dan cabai besar pada lahan lebak. Malang: BPTP Jawa Timur.

Subagyono, K., Dariah, A., Surmaini, E., \& Kurnia, U. (2008). Pengelolaan air pada tanah sawah, 193-222. Retrieved from http://balittanah.litbang.pertanian.go.id/ind/dokumentasi/buku/buku lahan sawah/07pengelolaan_air.pdf.

Sugiono, D., \& Saputro, N. W. (2016). Respon pertumbuhan dan hasil beberapa genotip padi (Oryza sativa L.) pada berbagai sistem tanam. Jurnal Agrotek Indonesia, 1(2), 105-116. https://doi.org/10.33661/jai.v1i2.341.

Surmaini, E., Runtunuwu, E., \& Las, I. (2015). Upaya sektor pertanian dalam menghadapi perubahan iklim. Jurnal Penelitian Dan Pengembangan Pertanian, 30(1), 1-7. https://doi.org/10.21082/jp3.v30n1.2011.p1-7.

Utami, S. N. H., Priyatmojo, A., \& Subejo. (2016). Penerapan teknologi tepat guna padi sawah spesifik lokasi di Dusun Ponggok, Trimulyo, Jetis, Bantul. Indonesian Journal of Community Engagement, 1(2), 239-254. https://doi.org/10.22146/jpkm.10610.

Yunizar. (2013). Pengelolaan Pupuk organik dan anorganik pada pola padi-padi dl Propinsi Riau. In Pertanian Organik: Solusi mewujudkan produksi pangan yang aman dan ramah lingkungan serta meningkatkan pendapatan petani (pp. 29-37). Yogyakarta: Jurusan Tanah Fakultas Pertanian UGM. 